\title{
Cytokeratin-19 mRNA-positive circulating tumor cells during follow-up of patients with operable breast cancer: prognostic relevance for late relapse
}

Emmanouil Saloustros ${ }^{1}$, Maria Perraki ${ }^{2}$, Stella Apostolaki ${ }^{2}$, Galatea Kallergi ${ }^{2}$, Alexandros Xyrafas ${ }^{1}$, Kostas Kalbakis ${ }^{1}$, Sophia Agelaki ${ }^{1}$, Antonia Kalykaki ${ }^{1}$, Vassilis Georgoulias ${ }^{1,2^{*}}$ and Dimitris Mavroudis ${ }^{1,2^{*}}$

\begin{abstract}
Background: The detection of cytokeratin-19 (CK-19) mRNA-positive circulating tumor cells (CTC) before and/or after adjuvant chemotherapy in patients with operable breast cancer is associated with poor clinical outcome. Reliable prognostic markers for late disease relapse are not available. In this study we investigated the value of CTC detection during the first five years of follow-up in predicting late disease relapse.

Methods: Blood was analyzed from 312 women with operable breast cancer who had not experienced disease relapse during the first two years of follow-up. A real-time reverse transcriptase polymerase chain reaction (RT-PCR) for CK-19 mRNA was used to detect CTC three months after the completion of adjuvant chemotherapy and every six months thereafter for a follow-up period of five years.
\end{abstract}

Results: Eighty patients (25.6\% of the study population) remained CTC free throughout the five-year period. A change in CTC status was observed in 133 patients (42.6\%); 64 patients (20.5\%) with initially CK-19 mRNA-positive CTC during the first 24 months turned CTC-negative afterwards while 69 (22.1\%) who were initially CTC-negative became CTC-positive. Ninety-nine patients (31.7\%) remained persistently CK-19 mRNA-positive. After a median follow-up period of 107 months (range: 38 to 161 months), the persistently CTC-positive patients with either hormonal receptor positive or negative tumors, had a higher risk of late-disease relapse compared to the persistently CTC-negative patients (36.4\% versus $11.2 \%, P<0.001)$. Multivariate analysis revealed that persistently CTC-positive patients also had a shorter disease-free $(P=0.001)$ and overall survival $(P=0.001)$.

Conclusions: Persistent detection of CK-19 mRNA-positive CTC during the first five years of follow-up is associated with an increased risk of late relapse and death in patients with operable breast cancer and indicates the presence of chemo-and hormonotherapy-resistant residual disease. This prognostic evaluation may be useful when deciding on subsequent adjuvant systemic therapy.

\section{Introduction}

Invasive breast cancer is the most common malignancy in women, accounting for 28 percent of new cancer cases and 15 percent of cancer deaths [1]. Due to declining mortality rates that are attributable mostly to the use of screening mammography and effective

\footnotetext{
* Correspondence: georgsec@med.uoc.gr; mavrudis@med.uoc.gr 'Department of Medical Oncology, University General Hospital of Heraklion, Voutes, Heraklion, 71110, Crete, Greece

Full list of author information is available at the end of the article
}

adjuvant therapy, more women nowadays survive their breast cancer [2]. Since metastatic disease is considered incurable, the early recognition and treatment of potentially still curable minimal residual disease is one of the major goals of care of breast cancer survivors and requires the in-depth understanding of relapse patterns.

Depending on the specific breast cancer type, the majority of recurrences occur during years 2 to 5 [3], although they can occur earlier or much later $[4,5]$. Especially for women with hormone receptor-positive

\section{C) Biomed Central}


disease, more than one-half of all recurrences and deaths occur beyond five years from diagnosis $[5,6]$. To date no tool is available for monitoring the effect of adjuvant treatment and in most cases the recurrence risk is calculated based on previous statistical analyses [7]. Therefore, with existing methods, prediction of the risk of relapse for the individual patient is limited.

Disseminated tumor cells (DTC) in bone marrow $[8,9]$ and circulating tumor cells (CTC) in peripheral blood $[10,11]$ of patients with operable breast cancer have been shown to be independent adverse prognostic factors for disease recurrence and disease-related death. Immunocytochemistry using antibodies against proteins that are expressed on epithelial but not on mesenchymal cells is widely used for the detection of DTC and CTC. However, the detection of mRNA transcripts for specific epithelial markers by using reverse transcriptase polymerase chain reaction (RT-PCR) and, more recently, the quantitative real-time RT-PCR (QPCR) seems to have higher diagnostic sensitivity [12]. The major advantage of RNA-based approaches is related to the rapid degradation of RNA released from cells in the blood by RNAses; therefore, the origin of detectable blood RNA transcripts is considered to be viable cells. Cytokeratin19 (CK-19), a cytoskeletal component present in normal and cancerous epithelial cells, has been extensively used for the detection of breast cancer cells in mesenchymal tissues and seems to be the most sensitive and reliable tumor marker in both patients with operable and metastatic breast cancer $[13,14]$.

Several studies have shown the prognostic significance of CK-19 mRNA-positive CTC in patients with operable breast cancer [10,11,15-17]. However, all these studies have investigated the prognostic value of CTC at the time of initial diagnosis and before the initiation and/or following the completion of adjuvant chemotherapy. Only a few reports exist concerning the clinical relevance of DTC, but none for CTC, during the surveillance period after the completion of adjuvant chemotherapy $[18,19]$. The unfavorable clinical outcome of patients with detectable isolated tumor cells in bone marrow was shown in the latter studies $[18,19]$. Given that DTC and CTC are theoretically the primary targets of adjuvant treatment, their fate after systemic therapy could be a potential useful marker permitting a direct and individualized assessment of treatment efficacy and a more accurate estimation of the risk of relapse.

In the present study, we sought to evaluate the clinical relevance of CK-19 mRNA-positive CTC detected by a QRT-PCR assay at different time points during the follow up period after the completion of adjuvant chemotherapy in patients with operable breast cancer. We hypothesized that patients presenting detectable CK-19 mRNA-positive CTC during follow-up despite the administration of adjuvant therapy, could be at an increased risk of late disease relapse (defined as relapse at least two years after the end of adjuvant chemotherapy) and death.

\section{Materials and methods}

\section{Patients and clinical samples}

We conducted a retrospective analysis of prospectively collected data in the context of an ongoing longitudinal study that has been previously reported [17]. Women with operable breast cancer (stage I to III) who were under surveillance and had not experienced disease relapse during the first two years of follow-up, were eligible for this study. All patients had received adjuvant chemotherapy mostly in the context of research protocols of the Hellenic Oncology Research Group. After completion of adjuvant chemotherapy, patients received adjuvant radiotherapy and hormonal therapy when indicated according to their individual disease characteristics. There were no subgroups of patients who received only adjuvant hormone therapy or no adjuvant systemic therapy at all.

Patients' follow-up consisted of pertinent medical history and physical examination, with laboratory and imaging studies restricted as indicated, every three months for the first two years, every six months for the next three years and yearly thereafter. All treating physicians were completely unaware of the CK-19 mRNA results for their individual patients and all follow-up laboratory and imaging studies to detect disease relapse were performed independently of the CK-19 mRNA results. All patients signed an informed consent to participate in the study, which was approved by the Ethics and Scientific Committees of our institution.

Cytokeratin-19 mRNA-positive CTC were monitored at specific time points after the completion of adjuvant chemotherapy for a five-year follow-up period. The first blood sample was obtained three months after the end of chemotherapy and subsequent samples were obtained every six months thereafter during the five-year followup.

Patients were classified into four groups based on their CTC status during the first two years and the subsequent three years of follow-up (as persistently negative, persistently-positive, negative turn to positive and the opposite). At least one CK-19 mRNA-positive blood sample in the corresponding period of time was required for classifying the patient in the CTC-positive group. On the other hand, if all the collected blood samples were negative for CK-19 mRNA, the patient was characterized as CTC-negative. Using this definition, the patients were classified in the "persistently CTC-negative" group, if there were no positive blood samples for CK-19 mRNA throughout the five-year follow-up 
period. On the other hand, the "persistently CTC-positive" patients had at least one positive blood sample for CK-19 mRNA in the first two years and at least another positive one in the subsequent three years of follow-up. Accordingly, patients in the "CTC-negative turn to positive" group had no positive samples in the first two years, but at least one positive sample in the next three years. The opposite was true for the "CTC-positive turn to negative" group.

\section{Blood samples and real-time RT-PCR for CK-19 mRNA}

Twenty milliliters $(\mathrm{mL})$ of peripheral blood in EDTA were collected at each visit. To avoid contamination with epithelial skin cells, all blood samples were obtained at the middle of vein puncture after the first $5 \mathrm{~mL}$ of blood was discarded. Peripheral blood mononuclear cells were obtained by gradient density centrifugation using FicollHypaque [10]. Total RNA isolation was carried out with the use of Trizol LS reagent (Gibco, Life Sciences, BRL, Grand Island, NY, USA) according to the manufacturer's instructions. The isolated RNA was dissolved in diethylpyrocarbonate-treated water and stored at $-80^{\circ} \mathrm{C}$ until used. RNA concentration was determined by absorbance reading at $260 \mathrm{~nm}$ with the Hitachi UV-VIS (U-2000) spectophotometer (Tokyo, Japan). The integrity was tested by PCR amplification of the $\beta$-actin housekeeping gene. As positive and negative controls we used RNA samples prepared from the MCF-7 breast cancer and ARH-77 leukemic cell lines respectively.

Reverse transcription of RNA was carried out with the Thermoscript RT-PCR system (Invitrogen, Paisley, UK). Complementary DNA (cDNA) was synthesized according to the manufacturer's instructions. The QPCR assays for the detection of CK-19 mRNA-positive cells, the primers and the details of the cycling protocol have been previously described [20]. Briefly, $2 \mu \mathrm{l}$ of cDNA were placed into an $8 \mu \mathrm{l}$ reaction volume containing $1 \mu \mathrm{l}$ of the sense primer CK-19-for $(3 \mathrm{mM}), 1 \mu \mathrm{l}$ of the antisense primer CK-19-do $(3 \mathrm{mM}), 2.4 \mu \mathrm{l}$ of the LightCycler Fast Start DNA Master Hybridization Probes reagent $(10 \times$ concentration), $1 \mu \mathrm{l}$ of the probe CK-19FL $(3 \mathrm{mM})$ and $1 \mu \mathrm{l}$ of the probe CK-19-LC $(3 \mathrm{mM})$ [15]. The quality of cDNAs was evaluated by real-time PCR for the housekeeping gene glyceraldehyde-3-phosphate dehydrogenase.

The presence of more than $0.6 \mathrm{MCF}-7$ cell equivalents $/ 5 \mu \mathrm{g}$ of total RNA was considered a positive result, according to the previously reported analytic detection limit of our assay [20]. Using this cutoff, only 2 of 89 (2.2\%) female healthy blood donors were positive for CK-19 mRNA-positive cells while none of 9 women with benign breast disease (fibroadenomas) had positive blood samples [20]. The high specificity of the method was made possible by avoiding contamination of skin epithelial cells during venipuncture, as well as by carefully designing the primers and hybridization probes. Hence, amplification of the known CK-19 pseudogenes and genomic DNA was avoided [20].

\section{Statistical analysis}

Disease-free survival (DFS), defined as the time from study entry until the day of the first evidence of disease recurrence, and overall survival (OS), defined as the time from study entry to death, were the main dependent variables of the study. The data-cut-off date was 20 July 2010. Kaplan-Meier curves for DFS and OS were compared using the log-rank test to provide a univariate assessment of the prognostic value of selected clinical risk factors. Clinicopathologic factors known to be associated with prognosis, such as menopausal status (premenopausal $v s$ postmenopausal), tumor size (T1 vs T23 ), number of the involved axillary lymph nodes (0 to 3 $v s \geq 4$ ), histological grade ( 1 or 2 vs 3 ), estrogen receptor (ER) status (negative vs positive), progesterone receptor (PR) status (negative vs positive) and HER-2/ $n e u$ status (negative $v s$ positive) were tested in univariate analysis. Variables that were found to be significant at the univariate screen were then entered in a stepwise multivariate Cox proportional hazards regression model to identify those with independent prognostic information. Entry into and removal from the model were set at $5 \%$ and $10 \%$, respectively. All statistical tests were performed at the 5\% level of significance. SPSS version 13 (SPSS Inc, Chicago, IL, USA) statistical software was used for the analysis. This report is written according to the reporting recommendations for tumor marker prognostic studies (REMARK criteria) [21].

\section{Results}

\section{Patients' characteristics}

A total of 455 consecutive patients with diagnosis of operable breast cancer treated and followed at the Department of Medical Oncology of the University Hospital of Heraklion between January 1997 and December 2004 were screened for eligibility for this study. A total of 412 (91\%) patients belong to the same cohort that was used to evaluate the prognostic significance of CK19 mRNA-positive CTC detection before initiation and/ or after completion of adjuvant chemotherapy [17].

A total of 143 patients were excluded for reasons listed in Figure 1 and 312 were included in the study. Patients' characteristics at the time of primary diagnosis in relation to CTCs status during follow-up are summarized in Table 1. The persistent detection of CTC during follow-up did not correlate with the patient's and/or tumor's characteristics, such as age $(p=0.197)$, menopausal status $(p=0.372)$, tumor size $(p=0.637)$, lymph node status $(p=0.082)$, histopathological grade 


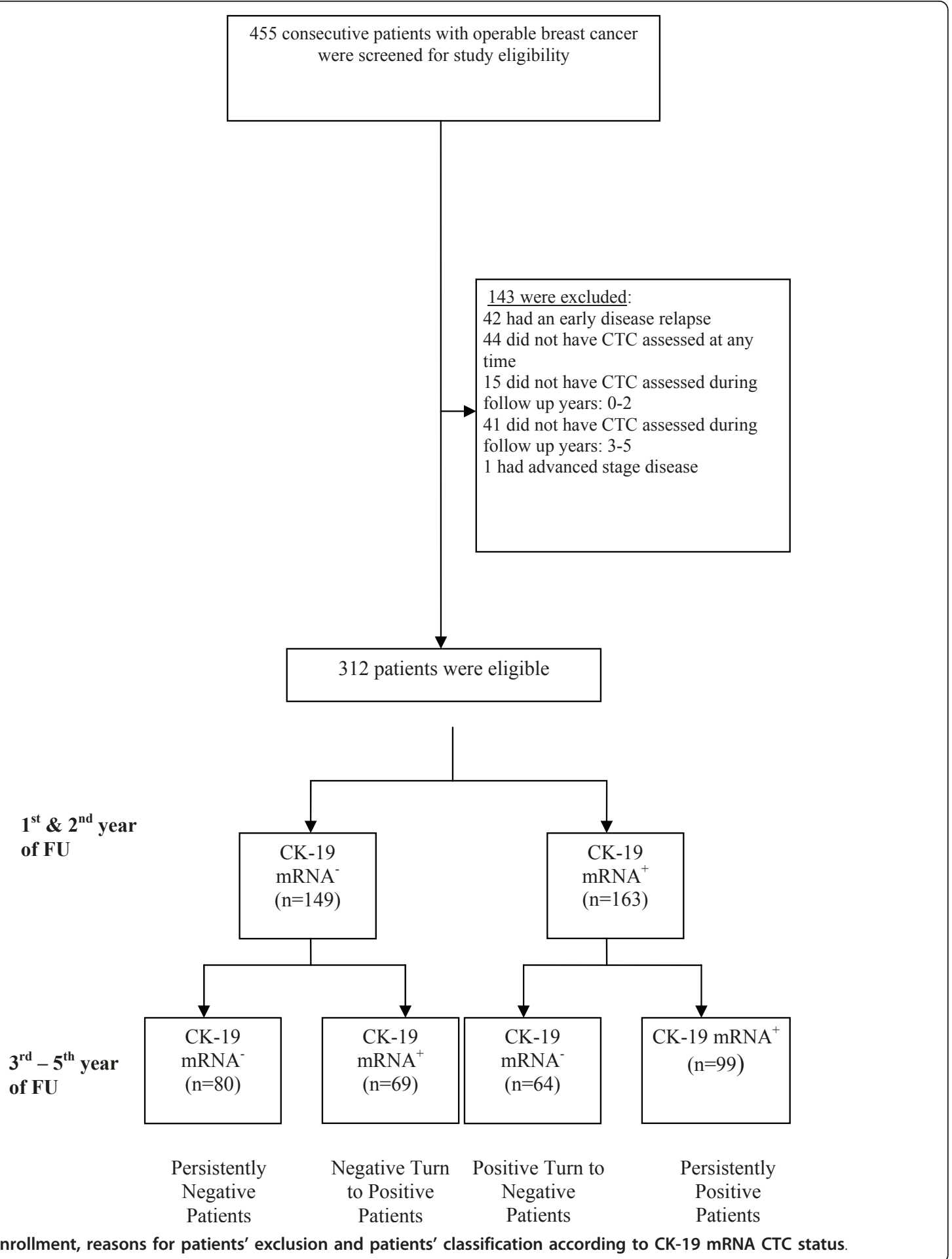

( $p=0.746)$ and hormone receptor status $(p=0.156)$. There was a difference in the type of adjuvant chemotherapy administered, with more patients in the persistently positive group having received anthracyclinebased regimens $(p=0.011)$.
Detection of CK-19 mRNA-positive cells during follow-up Cytokeratin-19 mRNA-positive cells were detected in the blood of 232 patients $(74.4 \%)$ at any time point during the five-year follow-up period, while 80 patients (25.6\%) remained CTC-free throughout the same period 
Table 1 Patients' characteristics at diagnosis according to CK-19 mRNA-positive cells during follow-up

\begin{tabular}{|c|c|c|c|c|c|c|c|}
\hline \multirow[t]{2}{*}{ Characteristics } & \multicolumn{2}{|c|}{ All Patients } & \multicolumn{2}{|c|}{ CK-19 mRNA-persistently negative } & \multicolumn{2}{|c|}{ CK-19 mRNA-persistently positive } & \\
\hline & $\mathrm{N}$ & $\%$ & $\mathrm{~N}$ & $\%$ & $\mathrm{~N}$ & $\%$ & \\
\hline Patients enrolled & 312 & & 80 & 25.6 & 99 & 31.7 & \\
\hline Age & & & & & & & $\begin{array}{l}\text { Mann-Whitney } \\
P=0.197\end{array}$ \\
\hline median (range) & $54(2$ & (77) & & & & & \\
\hline Menopausal status & & & & & & & $P=0.372$ \\
\hline Pre-menopausal & 145 & 46.5 & 41 & 51.3 & 44 & 44.4 & \\
\hline Post-menopausal & 167 & 53.5 & 39 & 48.8 & 55 & 55.6 & \\
\hline Tumor size & & & & & & & $\mathrm{T} 2 / \mathrm{T} 3$ vs $\mathrm{T} 1$ \\
\hline $\mathrm{T} 1$ & 116 & 37.2 & 30 & 37.5 & 33 & 33.3 & $P=0.637$ \\
\hline $\mathrm{T} 2$ & 174 & 55.8 & 43 & 53.8 & 59 & 59.6 & \\
\hline T3 & 22 & 7.1 & 7 & 8.8 & 7 & 7.1 & \\
\hline Lymph nodes & & & & & & & $P=0.082$ \\
\hline No & 107 & 34.3 & 33 & 41.3 & 28 & 28.3 & \\
\hline N1 to 3 & 119 & 38.1 & 29 & 36.3 & 35 & 35.4 & \\
\hline$N>3$ & 86 & 27.6 & 18 & 22.5 & 36 & 36.4 & \\
\hline Histology grade & & & & & & & $P=0.746$ \\
\hline $1 / 2$ & 159 & 51.0 & 39 & 48.8 & 56 & 56.6 & \\
\hline 3 & 119 & 38.1 & 28 & 35.0 & 36 & 36.4 & \\
\hline lobular & 34 & 10.9 & 13 & 16.3 & 7 & 7.1 & \\
\hline$H R$ & & & & & & & $P=0.156$ \\
\hline $\mathrm{ER}(-) / \mathrm{PR}(-)$ & 70 & 22.4 & 24 & 30.0 & 22 & 22.2 & \\
\hline Other & 190 & 60.9 & 39 & 48.8 & 60 & 60.6 & \\
\hline Unknown & 52 & 16.7 & 17 & 21.3 & 17 & 17.2 & \\
\hline HR and Her-2 & & & & & & & $P=0.116$ \\
\hline ER(-)/PR(-)/HER-2(-) & 52 & 16.7 & 19 & 23.8 & 16 & 16.2 & \\
\hline Other & 255 & 65.1 & 41 & 51.3 & 66 & 66.7 & \\
\hline Unknowm & 57 & 18.3 & 20 & 25.0 & 17 & 17.2 & \\
\hline Radiation therapy & & & & & & & $P=0.937$ \\
\hline No & 24 & 7.7 & 7 & 8.8 & 9 & 9.1 & \\
\hline Yes & 289 & 92.3 & 73 & 91.2 & 90 & 90.9 & \\
\hline Hormonotherapy & & & & & & & $P=0.103$ \\
\hline No & 23 & 7.4 & 10 & 12.5 & 5 & 5.1 & \\
\hline Yes & 289 & 92.6 & 70 & 87.5 & 94 & 94.9 & \\
\hline Type of hormonotherapy & & & & & & & $P=0.119$ \\
\hline No hormonotherapy & 23 & 7.4 & 10 & 12.5 & 5 & 5.1 & \\
\hline Als & 33 & 10.6 & 10 & 12.5 & 11 & 11.1 & \\
\hline $\mathrm{T}$ & 50 & 16.0 & 10 & 12.5 & 19 & 19.2 & \\
\hline Als \& $T$ & 57 & 18.3 & 9 & 11.3 & 22 & 22.2 & \\
\hline $\mathrm{LHRH}$ & 32 & 10.3 & 11 & 13.8 & 8 & 8.1 & \\
\hline $\mathrm{LHRH}+\mathrm{T}$ or Als & 117 & 37.5 & 30 & 37.5 & 34 & 34.3 & \\
\hline Chemotherapy & & & & & & & $P=0.011$ \\
\hline CMF & 30 & 9.6 & 11 & 13.8 & 4 & 4.0 & \\
\hline FEC & 149 & 47.8 & 31 & 38.8 & 57 & 57.6 & \\
\hline $\mathrm{T} / \mathrm{EC}$ & 133 & 42.6 & 38 & 47.5 & 38 & 38.4 & \\
\hline
\end{tabular}

Als, aromatase inhibitors; CMF, cyclophosphamide-methotraxate-fluorouracil; FEC, fluorouracil-epirubicin-cyclophosphamide; HR, hormone receptor; LHRH, luteinizing-hormone-releasing hormone; T, tamoxifen; T/EC, taxane/epirubicin-cyclophosphamide.

(persistently negative). More specifically, 99 patients (31.7\%) had persistently detectable CK-19 mRNA-positive cells both during the first two and the subsequent three years of follow-up (persistently-positive group). A change in CK-19 mRNA status was observed in almost half of patients (133 patients or 42.6\%). Of those, 64 patients (20.5\%) with initially detectable CK-19 mRNApositive cells during the first 24 months turned CTC- 
negative afterwards (positive turn to negative group), while 69 patients $(22.1 \%)$ who were initially CTC-negative became CTC-positive afterwards (negative turn to positive group) (Figure 1).

\section{Detection of CK-19 mRNA-positive cells and clinical outcome}

\section{Disease recurrence}

After a median follow-up period of 107 months (range: 38 to 161 months), 63 patients (20.2\%) had developed a distant $(n=56 ; 88.8 \%)$ or locoregional disease recurrence $(n=7 ; 11.2 \%)$ (Table 2$)$. Compared to the persistently negative patients, only the group of CK-19 mRNA-persistently positive patients had a significant higher risk of disease relapse (36.4\% versus $11.2 \%$; Fisher's exact test, $p<0.001)$. In fact, risk of disease recurrence was the highest in patients with persistentlypositive CTC (36.4\% versus $7.8 \% ; p<0.001$ and $36.4 \%$ versus $18.8 \% ; p=0.016$ compared to a positive turn to negative and a negative turn to positive group, respectively) (Table 2).

The five-year DFS rates were $82.5 \%$ versus $92.7 \%$ for persistently-positive versus persistently-negative patients, respectively. As illustrated in Figure 2A, persistently positive patients had a significantly shorter DFS than the persistently negative patients $(p<0.001)$. Although no group has as yet reached the median DFS, there was a progressive decrease in the DFS of the four groups of patients according to the detection of CK-19 mRNA-positive CTC during the five years of follow-up (Figure 2A).

\section{Survival}

Forty-one patients (13.1\%) died during follow-up as a result of disease progression. Twenty-four (58.5\%) and five $(12.2 \%)$ of these deaths occurred in the persistentlypositive and persistently-negative group, respectively (Fisher's exact test; $p=0.001$; Table 2). The 10-year overall survival rates were $81.4 \%$ for persistently-positive versus $96.7 \%$ for persistently-negative patients. Estimated median overall survival was significantly shorter for persistently positive compared to persistently negative patients $(p=0.013)$. Similar to DFS, there was a progressive decrease in the OS rates of the four groups of patients according to the detection of CK-19 mRNApositive CTC during the five years of follow up (Figure 2B).

\section{Subgroup analysis based on cumulative number of positive tests for pre-chemotherapy CTC status and hormone receptors}

Since patients underwent serial blood draws for the assessment of CK-19 mRNA-positive CTC, we analyzed our data to address the question whether the cumulative number of positive tests matters. Among patients with positive tests, $38.7 \%$ (during the first two years of follow-up), 24.4\% (during the subsequent three years) and $57.3 \%$ (during all the five years) had two or more positive test results (Additional file 1, Supplementary Table S1). No difference was found in the disease-free survival between the groups with different cumulative number of positive tests, probably due to the small number of patients and events in each group (Additional file 1: Supplementary Figure S1).

Given the prognostic role of the CTC detection before the administration of adjuvant chemotherapy [11], we investigated whether it could offer additional prognostic information to that of the serial measurements of CTC during follow-up. For this purpose, we reviewed the prechemotherapy CTC status of the patients included in this analysis (Additional file 1: Supplementary Table S2). No difference was found in the detection rate of the CK-19 mRNA-positive CTC between the four groups (Pearson chi-square, $p=0.320$ ). Interestingly, the persistently positive patients with detectable CK-19 mRNApositive CTC before the administration of adjuvant chemotherapy had shorter DFS but not OS compared to

Table 2 Incidence of disease recurrence and deaths according to the detection of CK-19 mRNA-positive circulating tumor cells

\begin{tabular}{|c|c|c|c|c|c|c|c|}
\hline \multirow[t]{2}{*}{ CK-19 mRNA } & \multirow[t]{2}{*}{ No of patients } & \multicolumn{2}{|c|}{ Relapses } & \multicolumn{4}{|c|}{ Deaths } \\
\hline & & $\begin{array}{l}\text { Yes } \\
\text { N (\%) }\end{array}$ & $\begin{array}{c}\text { No } \\
\text { N (\%) }\end{array}$ & Fisher's Exact test, $P$ & $\begin{array}{l}\text { Dead } \\
\text { N (\%) }\end{array}$ & $\begin{array}{l}\text { Alive } \\
\text { N (\%) }\end{array}$ & Fisher's Exact test, $P$ \\
\hline Persistently Positive & 99 & $36(36.4)$ & $63(63.6)$ & $P<0.001$ & $24(24.2)$ & $75(75.8)$ & $P=0.001$ \\
\hline Persistently Negative & 80 & $9(11.2)$ & $71(88.8)$ & & $5(6.3)$ & $75(93.8)$ & \\
\hline Positive Turn to negative & 64 & $5(7.8)$ & $59(92.2)$ & $\begin{array}{l}\qquad P<0.001 \\
\text { versus persistently positive }\end{array}$ & $3(4.7)$ & $61(95.3)$ & $\begin{array}{l}\qquad P=0.001 \\
\text { versus persistently positive }\end{array}$ \\
\hline
\end{tabular}

While also,

$P=.248$ for relapse of turn to positive versus persistently negative $P=.172$ for deaths of turn to positive versus persistently negative CK-19, cytokeratine-19. 
A

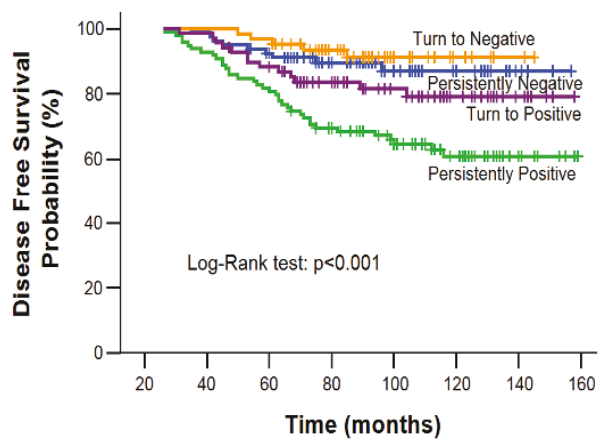

B

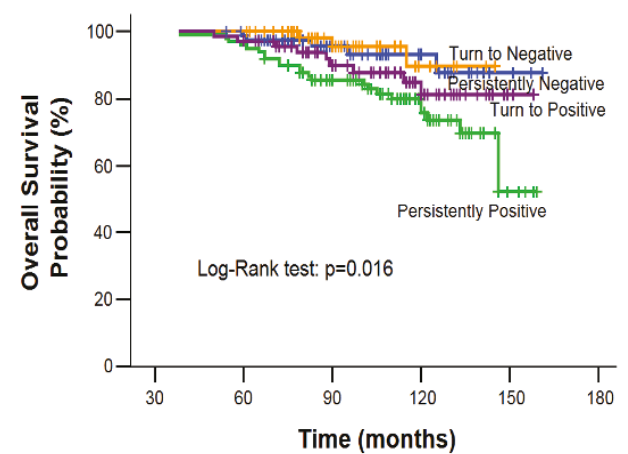

Figure 2 (A): Disease-free and (B): Overall Survival according to CTC detection during follow-up.

the patients of the same group who tested negative for pre-chemotherapy CK-19 mRNA-positive CTC (Additional file 1: Supplementary Figure S2).

Finally, a subgroup analysis was performed according to hormone receptor status. Interestingly, the persistently positive patients with either hormone receptor positive or negative tumors had a significantly higher relapse rate (Table 3), risk of death and shorter DFS than the persistently negative patients $[(p=0.039$ and $p$ $=0.004$ for persistently positive vs persistently negative patients with ER/PR negative and ER and/or PR positive tumors respectively) (Figure 3a, 3b)]. However, the overall survival was shorter only for the persistently positive patients with ER/PR negative tumors $(p=0.035$, Figures 3c, 3d).

\section{Univariate and multivariate analysis}

Persistent detection of CK-19 mRNA-positive CTC during the follow-up after the completion of adjuvant chemotherapy, tumor size greater than $2.0 \mathrm{~cm}$, more than three involved axillary lymph nodes and postmenopausal status were significantly associated with reduced DFS and OS in the univariate analysis (Table 4). Multivariate analysis revealed that persistent detection of CK-19 mRNA-positive CTC, tumor size and more than three involved axillary lymph nodes were independent prognostic factors for shorter DFS and OS (Table 5).

\section{Discussion}

We provide, to our knowledge, the first clear evidence of a strong correlation between detection of CK-19 mRNA-positive CTC during follow-up and increased risk of late disease relapse and death in patients with either hormonal receptor positive or negative operable breast cancer. These findings support the role of CTC monitoring as an adjunct to standard clinical and radiographic methods in the evaluation of disease status during follow-up.

Although the prognostic role of DTC for disease relapse and death in early breast cancer is clearly documented [8], the assessment of tumor cells in peripheral blood is easier, more broadly applicable than bone marrow aspirates and certainly more appropriate for repeated testing. Our group has previously reported that the detection of CK-19 mRNA-positive CTC in the blood of patients with node-negative operable breast cancer before the initiation of any systemic treatment was an independent prognostic factor associated with an increased risk of disease recurrence [11]. More recently, we demonstrated that the risk of relapse could be distinguished based on the response of their CTC to adjuvant chemotherapy [17] and we reviewed our experience regarding the prognostic role of CK-19 positive CTC in operable breast cancer [22]. Other investigators have shown that longitudinal monitoring of CTC was

Table 3 Incidence of Disease recurrence and deaths according to CTC detection and hormonal receptor status

\begin{tabular}{|c|c|c|c|c|c|c|c|c|}
\hline \multirow[t]{2}{*}{ HR Status } & \multirow[t]{2}{*}{ CK-19 mRNA } & \multirow[t]{2}{*}{ No of patients } & \multicolumn{2}{|c|}{ Relapses } & \multicolumn{4}{|c|}{ Deaths } \\
\hline & & & $\begin{array}{c}\text { Yes } \\
\text { N (\%) }\end{array}$ & $\begin{array}{c}\text { No } \\
\text { N (\%) }\end{array}$ & Fisher's Exact test, $P$ & $\begin{array}{l}\text { Dead } \\
\text { N (\%) }\end{array}$ & $\begin{array}{l}\text { Alive } \\
\text { N (\%) }\end{array}$ & Fisher's Exact test, $P$ \\
\hline \multirow[t]{2}{*}{$\overline{\mathrm{ER}(-) / \mathrm{PR}(-)}$} & Persistently Positive & 22 & $9(40.1)$ & 13(59.9) & $P=0.044$ & $8(34.4)$ & $16(63.6)$ & $P=0.009$ \\
\hline & Persistently Negative & 24 & $3(12.5)$ & $21(87.5)$ & & $1(4.1)$ & $24(95.9)$ & \\
\hline \multirow[t]{2}{*}{$\mathrm{ER}(+)$ and/or $\mathrm{PR}(+)$} & Persistently Positive & 60 & $26(43.3)$ & $34(46.7)$ & $P<0.001$ & $15(25)$ & $45(75)$ & $P=0.007$ \\
\hline & Persistently Negative & 39 & $4(10.2)$ & $35(89.2)$ & & $2(5.1)$ & $37(94.9)$ & \\
\hline
\end{tabular}

CK-19, cytokeratine-19; HR, hormonal receptor; ER, estrogens receptor; PR, progesterone receptor. 


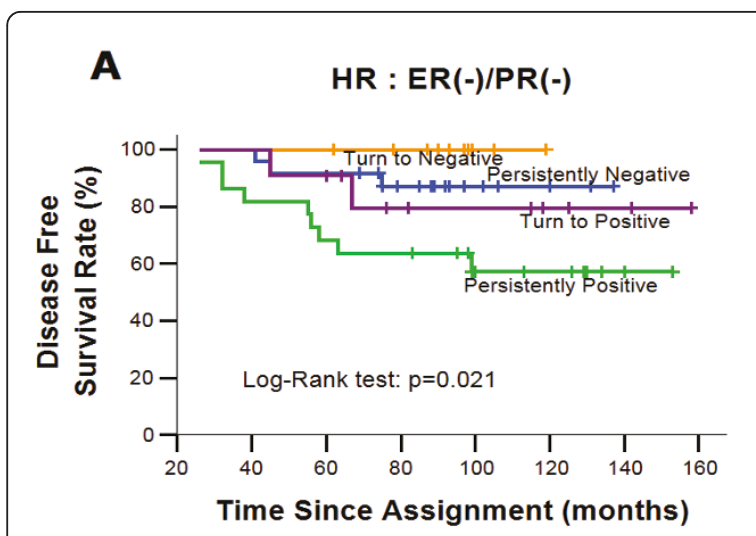

C

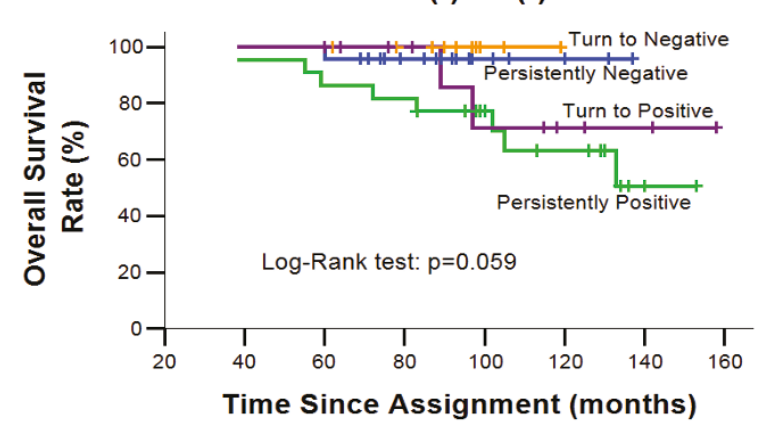

B

HR : ER(+) or/\& PR(+)

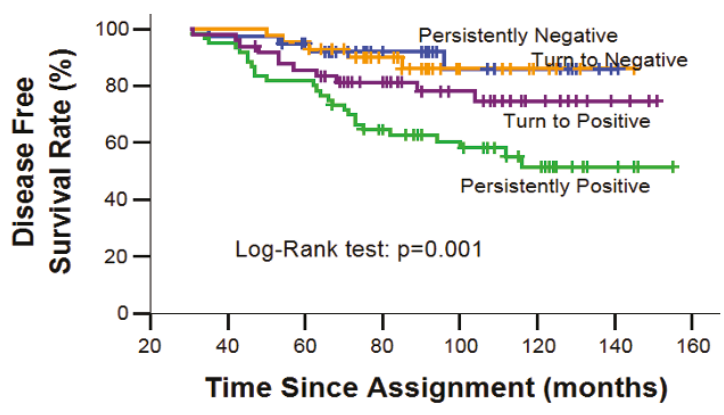

D HR : ER(+) or/\& PR(+)

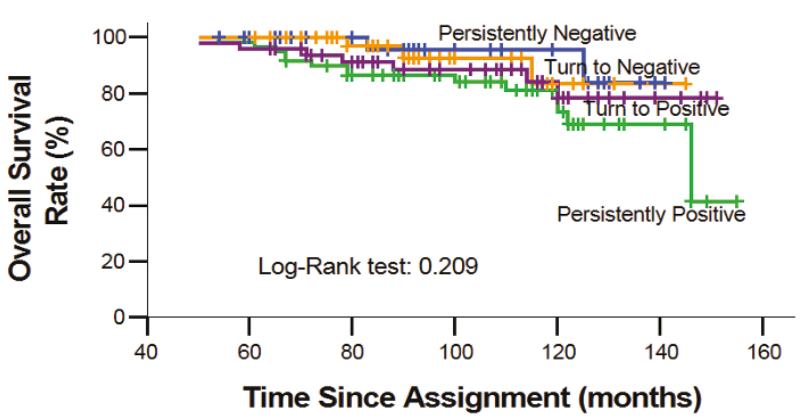

Figure 3 Disease-free and overall survival according to the CTC detection and hormone receptor status during follwow-up

superior to a single test analysis, and a more than 10fold increase in the CTC numbers towards the end of therapy is highly predictive for early relapse [23].

The present study was designed to investigate the prognostic value of CTC detection during follow-up in predicting the risk of late disease relapse. Accordingly, patients who experienced disease relapse during the first two years from diagnosis were excluded from this analysis and the median follow-up period was extended to 107 months. The changes in CK-19 mRNA-positive CTC status were thus analyzed in 312 patients and four groups were distinguished. The first group included patients without detectable CTC throughout the followup period, only $11.2 \%$ of whom experienced disease relapse. The second group included patients with CK-19 mRNA-positive CTC during the first two years. These patients had similar relapse risk to the persistently negative patients and might indeed have derived a benefit from the adjuvant therapy. In the third group patients with detectable CTC after, but not during, the first two years were included. The relapse risk for these patients was almost 50\% higher compared to the risk of persistently negative patients, presumably due to the growth of therapy-resistant residual disease, which could not be detected early on by our method. Finally, in the fourth group patients with CK-19 mRNA-positive CTC throughout the follow-up period were included. One third of them experienced disease relapse, while one out of four patients died. This persistently positive group was by far the group with the highest relapse risk.

Almost $40 \%$ of the "positive at any time" patients had detectable CK-19 mRNA-positive CTC only in one single sample. This observation could theoretically be attributed at least in part to false positive results. However, given the very low false positive rate of our assay (approximately $2 \%$ ) this occurrence should be rather limited.

Our results could be explained by the hypothesis that drug-resistant cancer cell clones generated during tumor evolution, constitute the re-emerging dominant tumor cell population and may start proliferating under the selective pressure of drug exposure. The high probability of subsequent disease relapse indicates that these resistant cells have a proliferative and survival advantage. This hypothesis seems to be supported by the observation (unpublished data) that the vast majority of CTC detected during the follow-up period from CK-19 mRNA persistently positive patients who had experienced disease relapse, did not express the M30 antigen which is a neo-epitope expressed only after caspase cleavage of cytokeratin 18 during early apoptosis [24,25]. 
Table 4 Univariate analysis (unadjusted relative risks) for disease-free and overall survival

\begin{tabular}{|c|c|c|c|c|c|c|}
\hline & \multicolumn{3}{|c|}{ DFS } & \multicolumn{3}{|c|}{ Overall survival } \\
\hline & HR & $95 \% \mathrm{Cl}$ & $P$-value & HR & $95 \% \mathrm{Cl}$ & $P$-value \\
\hline Menopausal status & & 1.075 to 3.064 & & & 1.027 to 3.836 & \\
\hline Post vs Pre & 1.815 & & 0.026 & 1.985 & & 0.041 \\
\hline Tumor status & & 1.304 to 4.419 & & & 1.710 to 11.114 & \\
\hline $\mathrm{T} 2 / \mathrm{T} 3$ vs $\mathrm{T} 1$ & 2.401 & & 0.005 & 4.359 & & 0.002 \\
\hline Nodes & & 1.418 to 3.832 & & & 1.527 to 5.207 & \\
\hline $\mathrm{N}>3$ vs N0-3 & 2.331 & & 0.001 & 2.819 & & 0.001 \\
\hline Histology grade & & 0.989 to 2.805 & & & 0.644 to 2.390 & \\
\hline 3 vs $1 / 2$ & 1.665 & & 0.055 & 1.240 & & 0.520 \\
\hline HR & & 0.454 to 1.504 & & & 0.585 to 2.387 & \\
\hline ER(-)/PR(-) vs other & 0.826 & & 0.533 & 1.182 & & 0.641 \\
\hline Triple negative & & 0.454 to 1.681 & & & 0.492 to 2.348 & \\
\hline ER(-)/PR(-)/HER-2 vs Other & 0.874 & & 0.686 & 1.075 & & 0.856 \\
\hline Hormonotherapy & & 0.696 to 3.759 & & & 0.442 to 4.687 & \\
\hline No vs Yes & 1.618 & & 0.264 & 1.439 & & 0.546 \\
\hline Chemotherapy & CMF (ref) & & 0.589 to 3.812 & & & 0.352 to 2.976 \\
\hline FEC & & & 0.339 & & & 0.911 \\
\hline \multirow[t]{2}{*}{ T/EC } & 1.498 & 0.389 to 2.745 & 0.396 & 1.024 & 0.388 to 3.564 & 0.966 \\
\hline & 1.034 & & 0.947 & 1.176 & & 0.775 \\
\hline $\begin{array}{l}\text { CK-19 at five years FU } \\
\text { Persistently negative } \\
\text { Turn to negative }\end{array}$ & $\begin{array}{l}0.300 \\
0.201 \\
0.498\end{array}$ & $\begin{array}{l}0.144 \text { to } 0.623 \\
0.079 \text { to } 0.513 \\
0.264 \text { to } 0.939\end{array}$ & $\begin{array}{l}0.001 \\
0.001 \\
0.031\end{array}$ & $\begin{array}{l}0.318 \\
0.260 \\
0.582\end{array}$ & $\begin{array}{l}0.121 \text { to } 0.836 \\
0.078 \text { to } 0.868 \\
0.271 \text { to } 1.253\end{array}$ & $\begin{array}{l}0.020 \\
0.028 \\
0.167\end{array}$ \\
\hline $\begin{array}{l}\text { Turn to positive } \\
\text { Persistently positive (ref) }\end{array}$ & & & $<0.001$ & & & 0.025 \\
\hline
\end{tabular}

CK-19, cytokeratine-19; CMF, Cyclophosphamide-Methotraxate-Fluorouracil; DFS, disease-free survival; FEC, Fluorouracil-Epirubicin-Cyclophosphamide; HR, hormone receptor; T/EC, Taxane/Epirubicin-Cyclophosphamide.

An algorithm for the optimal timing of CTC detection during follow-up is currently lacking. Our findings suggest that serial assessments every six months for up to five years represent an acceptable timetable. Furthermore, for hormone receptor positive patients, in whom half of the recurrences occur beyond the five years, extension of the CTC serial assessments for even longer might be reasonable. These patients may represent the group which could derive benefit from an extended adjuvant treatment approach or switch to another agent.
The QRT-PCR used in our study is not the only available assay for CTCs' detection. A semi-automated approach, the CellSearch ${ }^{\circledR}$ system (Veridex Raritan, NJ, USA), which has been approved by the Food and Drug Administration for monitoring CTC in the metastatic breast cancer setting, has gained considerable attention $[26,27]$. The prognostic relevance of CTC detection in the peripheral blood of operable breast cancer patients, using the CellSearch ${ }^{\circledR}$ system, has been evaluated in the SUCCESS trial. According to the most updated results,

Table 5 Prognostic factors by multivariate analysis for disease-free and overall survival

\begin{tabular}{|c|c|c|c|c|c|c|}
\hline & \multicolumn{3}{|c|}{ DFS } & \multicolumn{3}{|c|}{ Overall survival } \\
\hline & HR & $95 \% \mathrm{Cl}$ & $P$-value & HR & $95 \% \mathrm{Cl}$ & $P$-value \\
\hline $\begin{array}{l}\text { Menopausal status } \\
\text { Post vs Pre }\end{array}$ & 1.462 & 0.858 to 2.492 & 0.163 & 1.365 & 0.794 to 2.347 & 0.260 \\
\hline $\begin{array}{l}\text { Tumor status } \\
\text { T2/T3 vs T1 }\end{array}$ & 2.187 & 1.167 to 4.098 & 0.015 & 2.135 & 1.141 to 3.994 & 0.018 \\
\hline $\begin{array}{l}\text { Nodes } \\
N>3 \text { vs N0-3 }\end{array}$ & 1.801 & 1.080 to 3.003 & 0.024 & 2.150 & 1.109 to 4.168 & 0.023 \\
\hline $\begin{array}{l}\text { CK-19 at five years FU } \\
\text { Persistently negative } \\
\text { Turn to negative } \\
\text { Turn to positive } \\
\text { Persistently positive (ref) }\end{array}$ & $\begin{array}{l}0.328 \\
0.206 \\
0.622\end{array}$ & $\begin{array}{l}0.157 \text { to } 0.683 \\
0.081 \text { to } 0.526 \\
0.327 \text { to } 1.186\end{array}$ & $\begin{array}{l}0.003 \\
0.001 \\
0.149 \\
\mathbf{0 . 0 0 1}\end{array}$ & $\begin{array}{l}0.330 \\
0.201 \\
0.587\end{array}$ & $\begin{array}{l}0.159 \text { to } 0.688 \\
0.079 \text { to } 0.514 \\
0.309 \text { to } 1.115\end{array}$ & $\begin{array}{l}0.003 \\
0.001 \\
0.104 \\
\mathbf{0 . 0 0 1}\end{array}$ \\
\hline
\end{tabular}

CK-19, cytokeratine-19; CMF, cyclophosphamide-methotraxate-fluorouracil; DFS, disease-free survival; ER, estrogen receptor; FEC, fluorouracil-epirubicincyclophosphamide; PR, progesteron receptor; T/EC, taxane/epirubicin-cyclophosphamide. 
detection of at least one CTC in $23 \mathrm{~mL}$ of peripheral blood after surgical resection of the primary tumor and before the start of adjuvant systemic treatment was an independent predictor for worse DFS and OS in multivariate analysis [28]. The prognostic significance of CTC detection before and/or after the completion of adjuvant chemotherapy [17], as well as the high specificity/sensitivity represent some advantages of the QPCR assay compared to the CellSearch ${ }^{\circledR}$. On the other hand, the ability for direct enumeration, morphological analysis and isolation of CTC for further analysis are important advantages of the latter [29].

Our study has some potential limitations that should be taken into account when considering the results. This is a single institution study and the analysis was performed in one laboratory. Therefore, before the establishment of our assay as a clinically relevant test, sample analysis must be performed in several laboratories and stability during shipment must be demonstrated. Also and despite the fact that our assay has been validated in multiple cohorts and data analyses $[10,11,14,15,17]$, neither survival advantage, nor improvement in quality of life has been demonstrated in a prospective randomized trial. In this regard, the SWOG and the Breast Cancer Intergroup of North America have initiated a prospective trial in the metastatic setting to test whether patients with elevated CTC count (using the CellSearch ${ }^{\circledR}$ system) after one cycle of first-line chemotherapy will benefit from a switch to a different chemotherapeutic regimen (SWOG protocol S0500). However, for patients with operable breast cancer the lower CTC detection rate post-chemotherapy makes this strategy far more challenging $[28,30]$.

Additionally, the patients in our study received various types of adjuvant therapy based on available clinical and disease data at the time of enrolment. This heterogeneity may be a confounding variable, but the similarity between our findings on relapses $(20.2 \%)$ and those published by the Early Breast Cancer Trialists' Collaborative Group is encouraging [6]. Finally, the cellular heterogeneity of CTCs was not analysed using the QRT-PCR detection method. This is very important since various studies have already confirmed that CTC present significant genetic and phenotypic heterogeneity [31], which could explain why not all patients who have detectable CTC experience disease relapse, while some patients relapse although they do not present detectable CTC.

\section{Conclusions}

Our data support a prognostic role and potential clinical utility of monitoring CTC in conjunction with standard surveillance strategies for the follow-up of patients with operable breast cancer. Given their independent unfavorable prognostic value for reduced DFS and OS, the detection of CTC after therapy could be considered as indirect evidence for the presence of chemotherapy and hormonal therapy resistant disease. Analyzing a $20-\mathrm{mL}$ blood sample at various time points during follow-up might, therefore, enable clinicians to assess the efficacy of administered adjuvant therapy, limit patient exposure to ineffective agents with unnecessary toxicity, assist in the identification of patients who are most likely to benefit from clinical trials of novel therapeutics and perhaps make eradication of cancer cells more feasible, when the tumor burden is still low and before the appearance of clinically overt metastases. Since only one-third of patients with persistent CK-19 mRNA-positive CTC experience disease relapse, additional prognostic markers are needed to define better those patients who indeed might benefit from novel extended adjuvant therapies. These hypotheses can be addressed only in the context of well-designed, adequately powered, prospective, randomized clinical studies. In this way, definitive proof will be provided as to whether monitoring of the CTC can be used to improve clinical outcome in patients with operable breast cancer.

\section{Additional material}

Additional file 1: Supplemental material. Word document containing Supplementary Tables S1 and S2 and Supplementary Figures S1 and S2.

\section{Abbreviations}

cDNA: complementary deoxyribonucleic acid; CK-19: cytokeratin-19; CTC: circulating tumor cells; DFS: disease-free survival; DNA: deoxyribonucleic acid; DTC: disseminated tumor cells; ER: estrogen receptor; $\mathrm{mL}$ : milliliters; mRNA: messenger ribonucleic acid; OS: overall survival; PR: progesterone receptor; RT-PCR: real-time reverse transcription-polymerase chain reaction.

\section{Acknowledgements}

This work was supported by The Cretan Association for Biomedical Research (CABR) and Amgen Hellas.

\section{Author details}

'Department of Medical Oncology, University General Hospital of Heraklion, Voutes, Heraklion, 71110, Crete, Greece. 'Laboratory of Tumor Cell Biology, University of Crete, School of Medicine, Voutes, Heraklion, 71003, Crete, Greece.

\section{Authors' contributions}

ES participated in the design of the study, collected the data, analyzed the results and drafted the manuscript. MP, SA and GK: performed the laboratory work. KK, AK and SAg took care of the patients. AX performed the statistical analysis. VG and DM conceived and supervised the study and reviewed the manuscript. All authors have read and approved the final manuscript.

\section{Competing interests}

The authors declare that they have no competing interests.

Received: 12 January 2011 Revised: 2 May 2011

Accepted: 10 June 2011 Published: 10 June 2011 


\section{References}

1. Jemal A, Siegel R, Xu J, Ward E: Cancer statistics, 2010. CA Cancer J Clin 2010, 60:277-300.

2. Berry DA, Cronin KA, Plevritis SK, Fryback DG, Clarke L, Zelen M, Mandelblatt JS, Yakovlev AY, Habbema JD, Feuer EJ, Cancer Intervention and Surveillance Modeling Network (CISNET) Collaborators: Effect of screening and adjuvant therapy on mortality from breast cancer. $N$ Engl J Med 2005, 353:1784-1792

3. Jatoi I, Tsimelzon A, Weiss H, Clark GM, Hilsenbeck SG: Hazard rates of recurrence following diagnosis of primary breast cancer. Breast Cancer Res Treat 2005, 89:173-178.

4. Rosen PP, Groshen S, Kinne DW: Prognosis in T2N0M0 stage I breast carcinoma: a 20-year follow-up study. J Clin Oncol 1991, 9:1650-1661.

5. Saphner T, Tormey DC, Gray R: Annual hazard rates of recurrence for breast cancer after primary therapy. J Clin Oncol 1996, 14:2738-2746.

6. Early Breast Cancer Trialists' Collaborative Group (EBCTCG): Effects of chemotherapy and hormonal therapy for early breast cancer on recurrence and 15-year survival: an overview of the randomised trials. Lancet 2005, 365:1687-1717.

7. Bonadonna G, Moliterni A, Zambett M, Stefanelli M, Cipriani S, Valagussa P, Bonadonna $G$, Gianni $L$ : 30 years' follow up of randomised studies of adjuvant CMF in operable breast cancer: Cohort study. BMJ 2005, 330:217-220

8. Braun S, Vogl FD, Naume B, Janni W, Osborne MP, Coombes RC, Schlimok G, Diel IJ, Gerber B, Gebauer G, Pierga JY, Marth C, Oruzio D, Wiedswang G, Solomayer EF, Kundt G, Strobl B, Fehm T, Wong GY, Bliss J, Vincent-Salomon A, Pantel K: A pooled analysis of bone marrow micrometastasis in breast cancer. N Engl J Med 2005, 353:793-802.

9. Pantel K, Cote RJ, Fodstad O: Detection and clinical importance of micrometastatic disease. J Natl Cancer Inst 1999, 91:1113-1124.

10. Stathopoulou A, Vlachonikolis I, Mavroudis D, Perraki M, Kouroussis Ch, Apostolaki S, Malamos N, Kakolyris S, Kotsakis A, Xenidis N, Reppa D, Georgoulias V: Molecular detection of cytokeratin-19-positive cells in the peripheral blood of patients with operable breast cancer: Evaluation of their prognostic significance. J Clin Oncol 2002, 20:3404-3412.

11. Xenidis N, Perraki M, Kafousi M, Apostolaki S, Bolonaki I, Stathopoulou A Kalbakis K, Androulakis N, Kouroussis C, Pallis T, Christophylakis C, Argyraki K, Lianidou ES, Stathopoulos S, Georgoulias V, Mavroudis D: Predictive and prognostic value of peripheral blood cytokeratin-19 mRNA-positive cells detected by real-time polymerase chain reaction in node-negative breast cancer patients. J Clin Oncol 2006, 24:3756-3762.

12. Ring $A E$, Zabaglo L, Ormerod MG, Smith IE, Dowsett M: Detection of circulating epithelial cells in the blood of patients with breast cancer: comparison of three techniques. Br J Cancer 2005, 92:906-912.

13. Brown NM, Stenzel TT, Friedman PN, Henslee J, Huper G, Marks JR. Evaluation of expression based markers for the detection of breast cancer cells. Breast Cancer Res Treat 2006, 97:41-47.

14. Stathopoulou A, Mavroudis D, Perraki M, Apostolaki S, Vlachonikolis I, Lianidou E, Georgoulias V: Molecular detection of cancer cells in the peripheral blood of patients with breast cancer: comparison of CK-19, CEA and maspin as detection markers. Anticancer Res 2003, 23:1883-1890.

15. Xenidis N, Vlachonikolis I, Mavroudis D, Perraki M, Stathopoulou A Malamos N, Kouroussis C, Kakolyris S, Apostolaki S, Vardakis N, Lianidou E, Georgoulias V: Peripheral blood circulating cytokeratin-19 mRNA-positive cells after the completion of adjuvant chemotherapy in patients with operable breast cancer. Ann Oncol 2003, 14:849-855.

16. Quintela-Fandino M, Lopez JM, Hitt R, Gamarra S, Jimeno A, Ayala R, Hornedo J, Guzman C, Gilsanz F, Cortés-Funes H: Breast cancer-specific mRNA transcripts presence in peripheral blood after adjuvant chemotherapy predicts poor survival among high-risk breast cancer patients treated with high-dose chemotherapy and peripheral blood stem cell support. J Clin Oncol 2006, 24:3611-3618.

17. Xenidis N, Ignatiadis M, Apostolaki S, Perraki M, Kalbakis K, Agelaki S, Stathopoulos EN, Chlouverakis G, Lianidou E, Kakolyris S, Georgoulias V, Mavroudis D: Cytokeratin-19 mRNA-Positive Circulating Tumor Cells After Adjuvant Chemotherapy in Patients with Early Breast Cancer. J Clin Oncol 2009, 27:2177-2184

18. Wiedswang G, Borgen E, Karesen R, Qvist H, Janbu J, Kvalheim G, Nesland JM, Naume B: Isolated tumor cells in bone marrow three years after diagnosis in disease-free breast cancer patients predict unfavourable clinical outcome. Clin Cancer Res 2004, 10:5342-5348.
19. Janni W, Rack B, Schindlbeck C, Strobl B, Rjosk D, Braun S, Sommer H, Pantel K, Gerber B, Friese K: The persistence of isolated tumor cells in bone marrow from patients with breast carcinoma predicts an increased risk for recurrence. Cancer 2005, 103:884-891.

20. Stathopoulou A, Gizi A, Perraki M, Apostolaki S, Malamos N, Mavroudis D, Georgoulias V, Lianidou ES: Real-time quantification of CK-19 mRNApositive cells in peripheral blood of breast cancer patients using the LightCycler system. Clin Cancer Res 2003, 9:5145-5151.

21. McShane LM, Altman DG, Sauerbrei W, Taube SE, Gion M, Clark GM: Reporting recommendations for tumor marker prognostic studies. J Clin Oncol 2005, 23:9067-9072.

22. Saloustros E, Mavroudis D: Cytokeratin-19 positive circulating tumor cells in early breast cancer prognosis. Future Oncol 2010, 6:209-219.

23. Pachmann K, Camara O, Kavallaris A, Krauspe S, Malarski N, Gajda M, Kroll T, Jörke C, Hammer U, Altendorf-Hofmann A, Rabenstein C, Pachmann U, Runnebaum I, Höffken K: Monitoring the response of circulating epithelial tumor cells to adjuvant chemotherapy in breast cancer allows detection of patients at risk of early relapse. J Clin Oncol 2008, 26:1208-1215.

24. Leers MP, Kolgen W, Bjorklund V, Bergman T, Tribbick G, Persson B, Björklund P, Ramaekers FC, Björklund B, Nap M, Jörnvall H, Schutte B: Immunocytochemical detection and mapping of a cytokeratin 18 neoepitope exposed during early apoptosis. J Pathol 1999, 187:567-572.

25. Caulin C, Salvesen GS, Oshima RG: Caspase cleavage of keratin 18 and reorganization of intermediate filaments during epithelial cell apoptosis. J Cell Biol 1997, 138:1379-1394.

26. Riethdorf S, Fritsche H, Muller V, Rau T, Schindlbeck C, Rack B, Janni W, Coith C, Beck K, Jänicke F, Jackson S, Gornet T, Cristofanilli M, Pantel K: Detection of circulating tumor cells in peripheral blood of patients with metastatic breast cancer: a validation study of the CellSearch system. Clin Cancer Res 2007, 13:920-928.

27. Cristofanilli M, Budd GT, Ellis MJ, Stopeck A, Matera J, Miller MC, Reuben JM, Doyle GV, Allard WJ, Terstappen LW, Hayes DF: Circulating tumor cells, disease progression, and survival in metastatic breast cancer. $N$ Engl J Med 2004, 351:781-791.

28. Rack B, Schindlbeck C, Andergassen U, Lorentz R, Zwingers T, Schneeweiss A, Lichtenegger W, Bechmann MW, Sommer H, Pantel K, Friese K, Janni W, for the SUCCESS Study Group: Prognostic relevance of circulating tumor cells in the peripheral blood of primary breast cancer. Cancer Res 2010, , suppl: 93s.

29. Alix-Panabieres C, Sabine Riethdorf S, Pantel K: circulatingtumor cells and bone marrow micrometastasis. Clin Cancer Res 2008, 14:5013-5021.

30. Riethdorf S, Mueller V, Zhang L, Rau T, Loibl S, Komor M, Roller M, Houber J, Fehm $T$, Hilfrich J, Holms F, Tesch $\mathrm{H}$, Eidtmann $\mathrm{H}$, Untch $\mathrm{M}$, von Minckwitz G, Pantel K: Detection and Her-2 expression of circulating tumor cells: prospective monitoring in breast cancer patients treated in the neo-adjuvant GeparQuattro trial. Clin Cancer Res 2010, 16:2634-2645.

31. Kallergi G, Agelaki S, Kalykaki A, Stournaras C, Mavroudis D, Georgoulias V: Phosphorylation of FAK, PI-3K, and impaired actin organization in CKpositive micrometastatic breast cancer cells. Mol Med 2007, 13:79-88.

doi:10.1186/bcr2897

Cite this article as: Saloustros et al:: Cytokeratin-19 mRNA-positive circulating tumor cells during follow-up of patients with operable breast cancer: prognostic relevance for late relapse. Breast Cancer Research 2011 13:R60

\section{Submit your next manuscript to BioMed Central and take full advantage of:}

- Convenient online submission

- Thorough peer review

- No space constraints or color figure charges

- Immediate publication on acceptance

- Inclusion in PubMed, CAS, Scopus and Google Scholar

- Research which is freely available for redistribution 